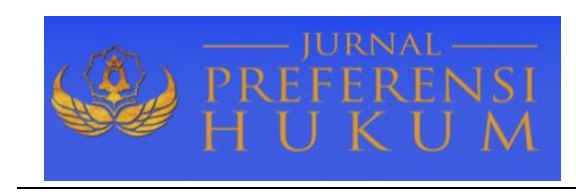

Jurnal Preferensi Hukum | ISSN: XXXX | E-ISSN: XXXX

Vol. 1, No. 2 - September 2020, Hal. 57-61| Available Online at https://www.ejournal.warmadewa.ac.id/index.php/juprehum

DOI: http://doi.org/10.22225/jph.v1i2.2342.57-61

\title{
PENENTUAN NILAI PEMUNGUTAN PAJAK BEA PEROLEHAN PERALIHAN TANAH OLEH PEMERINTAH DALAM PENYELENGGARAAN OTONOMI DAERAH
}

\author{
I Gede Chandra Astawa Widhiasa, I Wayan Arthanaya, Luh Putu Suryani \\ Fakultas Hukum Universitas Warmadewa, Denpasar-Bali, Indonesia
}

\begin{abstract}
Abstrak
Salah satu kewenangan yang dimiliki oleh pemerintah daerah adalah dalam hal pemungutan pajak salah satunya adalah Bea Perolehan Hak atas Tanah dan Bangunan (BPHTB) dilakukan oleh Badan Pendapatan Daerah. Dasar hukumnya adalah UU Nomor 28 tahun 2009. Hasil penerimaannya yang merupakan pendapatan negara sebagaian diserahkan kepada Pemerintah daerah untuk membiayai pembangunan di daerah dan guna mewujudkan otonomi daerah. Penelitian ini bertujuan untuk mengetahui dan mendeskripsikan dasar pengaturan pemerintah daerah menentukan nilai suatu obyek hak atas tanah sebagai obyek pajak dan menganalisa kewenangan melakukan pemungutan BPHTB dalam berkaitan dengan peraturan daerah. Peneliti menggunakan metode empiris yaitu pendekatan dengan aspek hukum dari hasil penelitian di lapangan melalui data- data yang dikumpulkan melalui wawancara dan observasi . Hasil penelitian dalam dasar penilaian BPHTB yang menjadi obyek penilaian tanah Dasar pengenaan BPHTB adalah hasil dari penilaian dari Perolehan Objek Pajak (NPOP). NPOP ditentukan dalam Pasal 87 Undang- undang No.28 Tahun 2009 tentang Pajak Daerah dan Retribusi Daerah. Bea perolehan hak atas tanah yang sebelumnya tidak dikenakan dalam hal peralihannya, dengan dikeluarkannya UU Nomor 21 Tahun 1997 yang kemudian diperbaharui dengan UU Nomor 21 Tahun 2000 yang memberikan kewenangan kepada pemerintah daerah dalam pengenaannya.
\end{abstract}

Kata Kunci: Penentuan Nilai Pajak; Pemerintah Daerah; Bea Perolehan Hak atas Tanah; Otonomi Daerah

\begin{abstract}
One of the authorities possessed by the regional government is in terms of tax collection, one of which is the Land Title Acquisition Fees (BPHTB) carried out by the Regional Revenue Agency. The legal basis is Law Number 28 of 2009. The proceeds of the revenue which constitute state revenue are handed over to the regional government to finance development in the regions and realize regional autonomy. This study aims to identify and describe the basis for local government regulations to determine the value of an object of land rights as a tax object and to regulate the authority to collect BPHTB in relation to local regulations. Researchers used an empirical method, namely an approach with legal aspects from the results of research in the field through data collected through interviews and observations. The results of research which are based on BPHTB which are the final results of BPHTB are the results of the Acquisition of Tax Objects (NPOP). NPOP is stipulated in Article 87 of Law No.28 of 2009 concerning Regional Taxes and Regional Levies. Fees for acquisition of land rights that were not previously imposed in the case of transfer, with the issuance of Law Number 21 of 1997 which was later bound by Law Number 21 of 2000 which gave regional government authority to impose it.
\end{abstract}

Keywords: Determination of Tax Value; Regional government; Land Title Acquisition Fees; Regional Autonomy

\section{PENDAHULUAN}

Dalam penyelenggaraan otonomi daerah salah satu yang paling mendasar adalah pelayanan terhadap masyarakat, hal ini merupakan penjabaran dari pembangunan nasional agar tercapai sasaran pembangunan dengan memerhatikan potensi daerah. Salah satu potensi yang dipunyai oleh pemerintah daerah adalah salah satunya pajak. Dikarenakan pengenaan pajak erat kaitannya dengan eksistensi manusia dan masyarakat dan dirinya. 
Dalam kaitannya dengan hal tersebut di atas, dibutuhkan ada nya organisasi yang lebih besar yang dapat menjamin kelangsungan hidup dan juga meningkatkan kesejahteraan masyarakat. Hal ini membuat masyarakat bergabung membentuk komunitas yang lebih besar, yang dikenal sebagai negara. Sekumpulan orang yang menempati suatu wilayah disebut masyarakat, Negara terbentuk karena ada nya kumpulan kelompok masyarakat dengan kepentingan yang sama dan keyakinan yang sama untuk meningkatkan kesejahteraannya (Siahaan, 2001). Sedangkan pemerintah dibentuk untuk menjalankan fungsi dari suatu negara tersebut tentunya dengan sikap yang bertanggung jawab.

Pemerintah memerlukan anggaran yang tidak sedikit, agar terciptanya suatu tatanan masyarakat yang sejahtera oleh sebab itu negara akan mencari biaya tersebut dengan melakukan pemungutan pajak. Negara sebagai organisasi memiliki fungsi sebagai pemungut pajak yang sebagai fungsi yang sangat penting. Apabila suatu negara tidak melakukan pemungutan pajak sudah dapat dipastikan keuangan negara akan defisit dan akan mengakibatkan perkembangan dan kesejahteraan masyarakat tidak akan tercapai.

Satu jenis pungutan yang dikenakan adalah tanah dan/atau bangunan adalah BPHTP. Orang perorangan dan badan hukum dalam Perolehan hak atas tanah dan/atau bangunan merupakan perbuatan atau peristiwa hukum yang menyebabkan dipenuhinya atau diperolehnya hak atas tanah dan/atau bangunan. Peraturan dasar pokok-pokok dasar agraria/ UU Nomor 5/1960 juga mengatur berkaitan dengan peralihan hak -hak atas tanah.

Kewenangan dimiliki oleh pemerintahan daerah adalah memungut pajak BPHTB adalah Badan Pendapatan Daerah sebagaimana diatur dalam undang- undang nomor 28 Tahun 2009 tentang Pendapatan Daerah dan Retribusi Daerah selain itu undang-undang ini dibuat untuk menyederhanakan sistem administrasi perpajakan dan retribusi daerah dan menyederhanakan berbagai pajak daerah serta mengurangi biaya ekonomi yang tinggi agar dapat memperkuat fondasi penerimaan/pendapatan daerah.

Sebelumnya yang memungut Pajak BPHTB adalah pemerintah pusat kemudian pada saat ini yang berwenang memungut adalah pemerintah daerah ini berarti ada pengalihan kewenangan dalan pemungutan pajak BPHTB. Pengalihan kewenangan BPHTB tidak hanya sebatas pungutan/penagihan melainkan juga pada seluruh penilaian, pendataan, pelayanan, penetapan disamping pengadministrasian yang juga harus dilaksanakan oleh pemerintahan daerah yang berdasarkan Peraturan Daerah mengenai pemungutan BPHTB. Untuk itu agar dapat di pungut pada suatu daerah, pemerintah kabupaten/kota harus terlebih dahulu menerbitkan dasar hukum tentang BPHTB yang akan menjadi pedoman operasional dalam teknis pelaksanaan pengenaan dan pemungutan BPHTB di daerah kabupaten/kota yang bersangkutan.

Berkaitan dengan penelitian terdahulu oleh (Widayat, 2016) dalam penelitiannya menyimpulkan bahwa pelaksanaan pemungutan Bea Perolehan Hak atas Tanah dan Bangunan dalam proses jual beli tanah dan bangunan di Kabupaten Kebumen diatur dengan sistem self assessment yang memberikan kepercayaan kepada Wajib Pajak untuk menghitung, memperhitungkan, membayar sendiri pajak yang terhutang dengan menggunakan formulir SSPD BPHTB yang diperoleh oleh Wajib Pajak dari DPPKAD Kabupaten Kebumen.

Berdasarkan pemaparan sebelumnya, adapun rumusan masalah yaitu apa dasar pemerintah daerah dalam menjalankan kewenangan di bidang pemungutan BPHTB? Serta bagaimana dasar penilaian BPHTB yang menjadi obyek penilaian tanah?. Tujuan dari penelitian ini adalah untuk mengetahui dan mendeskripsikan siapa yang berwenang melakukan pemungutan BPHTB berkaitan dengan Peraturan Daerah Kabupaten berkaitan bea perolehan hak atas tanah dan bangunan. Tujuan umum dari penelitian ini ditujukan untuk memberikan pemahaman dan pengetahuan yang memiliki keterkaitan dengan BPHTP kepada masyarakat .

\section{METODE PENELITIAN}

Peneliti menggunakan metode empiris yaitu pendekatan dengan aspek hukum dari hasil penelitian di lapangan melalui data- data yang dikumpulkan melalui wawancara dan observasi (Soemitro, 1988). Bahan hukum yang dipergunakan dalam penulisan ini adalah bahan hukum primer dan bahan hukum sekunder, kemudian di analisa. Upaya pencarian dilakukan dengan melakukan riset atau penelitian dengan objek yang diteliti yang menjadi pegangan dalam menyelesaikan permasalahan yang diteliti (Sunggono, 2011). Selanjutnya pendekatan yang dipergunakan adalah pendekatan 
perundang-undangan atau statute approach), pendekatan konseptual (concept approach) dan pendekatan analitis. Kemudian bahan-bahan hukum yang dipergunakan seperti perundang- undangan yang berkaitan dengan pokok bahasan, serta bahan hukum sekunder antara lain buku-buku yang berkaitan dengan isu yang dibahas.

\section{HASIL DAN PEMBAHASAN}

\section{Dasar Pengaturan Pemerintah Daerah Menentukan Nilai Suatu Obyek Hak atas Tanah}

Terdapat beberapa perubahan mendasar yang terjadi, yang membedakan antara undang-undang nomor 32 tahun 2004 dengan Undang-undang nomor 23 tahun 2014. Hal ini paling terlihat adalah ditetapkannya urusan wajib, ditetapkannya pola hubungan yang sifatnya konkuren matara pemerintah pusat, pemerintah propinsi dan pemerintah $\mathrm{Kab} /$ kota. (lihat penjelasan dalam peraturan pemerintah nomor 38 tahun 2007 tentang Pembagian urusan pemerintah antara pemerintah, pemerintah daerah propinsi dan pemerintah Daerah Kab/ kota). Menguraikan pola hubungan antara pemerintah pusat dengan pemerintah daerah, (Manan, 2011) berpendapat paling tidak ada 4 (empat) faktor-faktor yang menentukan hubungan pusat dan daerah dalam otonom, yaitu: hubungan kewenangan, hubungan keuangan dan hubungan pengawasan serta hubungan yang timbul dari susunan organisasi pemerintah daerah (Manan, 2011). Mengenai jenis peraturan perundang-undangan menurut ketentuan pasal 7 ayat (1) Undang-undang Nomor 12 Tahun 2011 tentang Pembentukan Peraturan Perundangundangan terdiri dari atas : Undang-undang dasar negara republik Indonesia. TAP MPR UU/PERPU PP Perda Provinsi Perda Kab/Kota Kemudian, pasal 8 ayat (1) Undang-undang nomor 12 tahun 2011 menetapkan perluasan berbagai jenis peraturan perundang-undangan melainkan yang dimaksud dalam pasal 7 ayat (1) meliputi peraturan yang ditetapkan oleh MPR, DPR, DPD, MA dan lembaga-lembaga lainnya.

Prinsip hukum yang perlu diperhatikan dalam menyusun suatu materi muatan peraturan perundang-undangan yang harmonis antara lain adalah : Larangan ada nya kekosongan hukum atau norma Larangan ada nya norma kabur dalam perundang-undangan dan adanya konflik norma baik secara internal maupun eksternal (Manan, 2011). Perubahan UU tentang pemerintahan Daerah memberikan kebebasan perlu penyusunan pembangunan daerah kabupaten/kota yang bersinergi dengan pembangunan daerah provinsi (pasal 10), kemudian kaitannya dengan peralihan atas tanah di perlukan pengaturan yang lebih khusus seperti pengenaan pajak terhadap peralihan hak tanah. Dimana dilakukan antara individu dengan individu dan ada pelibatan terhadap pemerintah dalam hal ini adalah pemerintah daerah dalam hal pengenaan pajak. Peralihan yang dimaksudkan seperti hibah, wasiat maupun jual beli.

Dalam perjanjian pemindahan harta tetap yang ada di wilayah Indonesia akan dipungut Bea Balik Nama, termasuk peralihan harta karena hibah wasiat. Ordonansi Balik Nama Staatsblaad 1834 Nomor 27, yang merupakan landasan pengaturan hak-hak kebendaan dalam peralihannyadi bidang harta benda yang bersifat tetap (Supriyanto, 2010). UUPA sebagai peraturan dasar di bidang pertanahan mengatur yang berkaitan dengan hak atas tanah, antara lain HGBm HM dan dan peralihan hak lainnya. Bea perolehan hak atas tanah yang sebelumnya tidak dikenakan dalam hal peralihannya, dengan dikeluarkannya UU Nomor 21 Tahun 1997 yang kemudian diperbaharui dengan UU Nomor 21 Tahun 2000 yang memberikan kewenangan kepada pemerintah daerah dalam pengenaannya.

\section{Analisa Kewenangan Melakukan Pemungutan BPHTB dalam Berkaitan dengan Peraturan Daerah}

Dalam penyelenggaraan desentralisasi, ada beberapa pengalihan dalam hal kewenangan dalam pemungutan pajak, yakni BPHTB. Sebagai dasar hukumnya adalah dalam hal Pengalihan tersebut diatas adalah UU No. 28 Tahun 2009 tentang Pajak Daerah dan retribusi Daerah. Pengaturan mengenai objek pajak, subjek pajak, serta tata cara perhitungan dan dasar dari pengenaan BPHTB yang terdapat dalam ketentuan UU No. 28 Tahun 2009, adalah sama dengan pengaturan BPHTB sebagaimana yang diatur sebelumnya dalam UU No. 21 Tahun 1997 yang kemudian telah diubah dengan UU No. 20 Tahun 2000 (Hartoyo, 2010).

Namun ada beberapa perbedaannya diantara nya yaitu ada nya pengalihan kewenangan pemungutan jenis pajak yang semula dipungut oleh pemerintah pusat namun sekarang dialihkan 
kewenangannya kepemerintah daerah hal ini tercantum di ketentuan pasal dalam UU No. 28 Tahun 2009. (lihat penjelasan dalam pengaturan pajak retribusi dan dan Pajak 2010: 67)

Tentunya dengan dialihkannya beberapa jenis pajak pusat menjadi pajak daerah melalui UU No. 28 Tahun 2009, akuntabilitas penyelenggaraan otonomi daerah akan meningkat, kemudian kewenangan yang di miliki oleh pemerintah daerah di bidang perpajakan dalam peningkatan pendapatan semakin meningkat pula dalam hal pendapatan di bidang pajak daerah (Hartoyo, 2010). Ketentuan hukum Pemerintah darah dalam Pengenaan pajak Atas Tanah Dan Bangunan.

Dalam pemerintah Provinsi yang dipimpin oleh seorang Gubernur dan pemerintah kabupaten/kota yang dipimpin oleh Bupati/ Walikota, , jenis pajak di daerah ada (dua) yaitu pajak provinsi dan pajak kabupaten/kota. Untuk melaksanakan otonomi daerah secara utuh, pemerintah pusat kemudian melakukan pengalihan beberapa pajak yang di atur di dalam UU No. 28 Tahun 2009 yaitu Pajak Daerah dan Retribusi Daerah awalnya merupakan pajak pusat menjadi pajak daerah. (Lihat penjelasan dalam ketentuan perundang-undangan pajak daerah dan retribusi: Ibid) Pemerintah daerah melakukan Iuran wajib terhadap perorangan dan individu ataupun badan yang tanpa mendapatkan imbalan atau kontraprestasi secara langsung yang seimbang disebut dengan pajak daerah, dipaksakan berdasarkan beberapa peraturan yang berlaku, seperti peraturan daerah (Perda). Ketentuan dalam Pajak daerah diatur dalam UU Nomor 28 Tahun 2009, Pasal 1 angka 10 pajak daerah adalah Pajak Daerah disebut Pajak, adalah kontribusi wajib yang dilakukan oleh badan atau individu yang bersifat memaksa yang disetorkan kepada Pemerintah Daerah yang berdasarkan undang-undang, dengan tidak mendapatkan imbalan secara langsung dan digunakan untuk keperluan Daerah bagi sebesar-besar nya untuk kepentingan kemakmuran rakyat. (Penjelasan dalam Undang-undang Nomor 28 Tahun 2009 tentang ketentuan Pajak Daerah dan Retribusi daerah.) Pembagian jenis pajak yang dipungut dengan menggunakan peraturan perundang-undangan yang lebih tinggi yaitu UU No. 28 Tahun 2009 sebagai pedomannya, ini merupakan bentuk nyata pemberian kewenangan pemerintah daerah oleh pemerintah pusat untuk melakukan pemungutan pajak. Terdapat empat (4) macam pungutan Pajak baru bagi Daerah, yaitu Bea Perolehan Hak atas Tanah dan Bangunan yang sebelumnya merupakan pajak pusat, Pajak Bumi dan Bangunan Perdesaan dan Perkotaan, dan Pajak Sarang Burung Walet sebagai Pajak kabupaten/kota serta Pajak Rokok yang merupakan Pajak baru bagi provinsi. (lihat Penjelasan dalam Undang-undang tentang Pajak Daerah dan Retribusi daerah.)

Fungsi dari pajak daerah ini berfungsi untuk biaya penyelenggaraan pemerintah dan rumah tangga daerah, dimana nantinya pajak akan digunakan seluas-luasnya untuk membangun daerah guna terciptanya masyarakat yang makmur dan sejahtera. Dinas Pendapatan Daerah merupakan bagian dari pemerintah yang berwenang untuk melakukan pemungutan dari pajak.

Perubahan UU Nomor 23 Tahun 2014 yang awalnya Undang-undang Nomor 32 Tahun 2004, dalam penyelenggaraan kewenangan daerah dalam pemungutan beberapa jenis pajak yang awalnya merupakan pajak yang dipungut oleh pemerintah pusat, dalam penyelenggaraan otonomi daerah menjadi kewenangan pemerintah daerah. Dalam hal ini mewujudkan pemerintah daerah yang mandiri dan memberikan peluang penguatan kepada pemerintah daerah dalam bidang ekonomi. Untuk peningkatan dibidang pendapatan pajak. Otonomi seluas-luas nya merupakan pengejawantahan prinsip otonomi daerah mengandung arti bahwa diluar yang menjadi urusan pemerintah pusat, pemerintah pusat memberikan kewenangan kepada pemerintah daerah untuk mengatur dan mengurus semua satuan pemerintahannya. Penyelenggaraan otonomi daerah sebagi penjabaran asas desentalisasi dengan memberikan kewenangan kepada daerah khususnya pemerintah kab/kota. Pertanggungjawaban dalam prinsip otonomi daerah, dilaksanakannya prinsip otonomi yang nyata dan bertanggung jawab. Selanjutnya prinsip otonomi nyata, berkaitan dengan urusan pemerintahan yang dilaksanakan berdasarkan wewenang, tugas dan kewajiban yang senyatanya ada dan berpotensi untuk tumbuh, hidup serta berkembang (South, 2013). Penerapan otonomi daerah akan berdampak pada penerapannya di masing- masing daerah, dan mempunyai karakteristik dimasing-masing daerah. Bidang perpajakan yang menjadi kewenangan Pemerintah Pusat sebelumnya yang kemudian dialihkan pemungutannya menjadi kewenangan Pemerintah Daerah,menegenai subtansi dan materinya adalah sama. Kewenangan memungut terhadap peralihan biaya hak atas Tanah dan Bangunan, salah satunya adalah pajak yang dialihkan kewenangannya. Hal mana tujuannya adalah guna meningkatkan pendapatan asli daerah masing-masing daerah. 
Jenis pajak daerah yang pemungutannya dilakukan oleh Pemerintah daerah adalah BPHTB, dasar yang menjadi pertimbangan adalah luas tanah dalam suatu wilayah sebagai objek pajak BPHTB, jual beli tanah sebagai objek pajak, peraliahan hak-hak atas tanah dan bangunan sebagai objek pajak BPHTB. Dan segala bentuk peralihan dibidang pertanahan yang dilakukan di daerah yakni kab/Kota. Pemikiran terkait dengan penyerahan kewenangan yang dilakukan pemerintah pusat kepada pemerintah daerah dalam hal pemungutan pajak adalah untuk memberikan pelayanan yang baik kepada masyarakat yang ada didaerah. Masyarakat didaerah menginkan pelayanan yang baik dari pemerintah daerah kabupaten/kota adalah tanggung jawab dari ada nya hubungan antara rakyat dengan pemerintah daerah $\mathrm{Kab} / \mathrm{kota}$.

Tujuannya diberikan kewenangan dalam hal pemungutan pajak daerah di bidang bea perolehan hak atas tanah adalah untuk meningkatan pendapatan daerah Kab/kota. Dengan meningkatnya pendapatan daerah maka kemandirian di daerah menjadi kuat. Baik dibidang fiskal dan dibidang ekonomi yang menjadi salah satu indikator dalam mengukur suatu daerah mandiri dalam pelaksanaan otonomi daerah. Salah satunya adalah keberadaan pajak BPHTB menjadi pajak daerah. Dengan keberadaan dari BPHTB ini lah yang menjadi sumber pendapatan bagi daerah dalam peningkatan asli daerah, sehingga memperkuat kemandirian di bidang ekonomi dan serta tanggung jawab dari pemerintahan daerah. Pemerintah pusat memberikan keleluasaan kepada pemerintah daerah dengan asas desentralisasi guna meningkatkan dan kesejahteraan masyarakat dengan tetap mempertimbangkan asas keadilan dan pemerataan.

\section{SIMPULAN DAN SARAN}

\section{Simpulan}

Berdasarkan uraian tersebut diatas dapat di kemukakan kesimpulan sebagai berikut:

Pemerintah Daerah mengatur kewenangan pemungutan BPHTB yang bertujuan untuk meningkatkan kesejahteraan masyarakat melalui kewenangannya dengan melakukan pemungutan dengan tidak mendapatkan imbalan secara langsung. Pemerintah daerah melakukan pengenaan iuran wajib berupa pajak daerah terhadap individu, badan hukum dengan tanpa kontraprestasi langsung dan seimbang, dan sifatnya dipaksakan berdasarkan ketentuan hukum yang ada, seperti peraturan yang dibuat di daerah. Dasar penilaian BPHTB yang menjadi obyek penilaian tanah Dasar pengenaan nya adalah (NPOP). NPOP ditentukan dengan ketentuan yang diatur Pasal 87 Undang- undang No.28 Tahun 2009 yakni mengenai Pajak Daerah dan Retribusi Daerah. Penentuan pengenaan pajak, dapat diberikan keringanan terhadap individu atau badan hukum yang ditentukan dengan penghitungan objek yang dinilai dan yang bebas dari pungutan pajak.

\section{Saran}

Disarankan kepada pemerintah Daerah untuk mengatur pengenaan BPHTB secara tegas karena masih banyak obyek hak atas tanah yang belum menjadi sasaran obyeknya. Disarankan kepada masyarakat agar tetap taat dalam berkontribusi terhadap pengenaan pajak BPHTP guna meningkatkan pendapatan daerah. Kepada instansi (badan pendapatan daerah) agar tetap melakukan pengawasan terhadap pelaksanaan pemungutan pajak yang dilakukan oleh aparaturnya.

\section{DAFTAR PUSTAKA}

Hartoyo, H. S. U. (2010). Membedah Pengelolan Administrasi Pajak BB dan BPHTB. Mitra wacana Media.

Manan, B. (2011). Komentar Undang-Undang Pemerintah Daerah. Alumni Bandung.

Siahaan, M. P. (2001). Hukum Pajak Elementer (Konsep Dasar Perpajakan Indonesia). Graha Ilmu.

Soemitro, R. H. (1988). Metode Penelitian Hukum dan Jurimetri. Univ. Katholik Atmajaya Indonesia.

South, J. D. (2013). Kewenangan Daerah Mengelola Bea Perolehan Hak Atas Tanah Dan Bangunan. Jurnal Hukum Universitas Samratulangi, 1(5).

Sunggono, B. (2011). Metode Penelitian Hukum. Raja Grafindo Persada.

Supriyanto, H. (2010). Cara Menghitung Pajak Bumi Bagunan. Indeks.

Widayat, A. W. (2016). Analisis Pengenaan Bea Perolehan Hak Atas Tanah dan Bangunan dalam

Proses Jual Beli Tanah dan Bangunan di Kabupaten Kebumen. Lex Renaissance, 1(2). 